IZA DP No. 9209

Crime and Establishment Size:

Evidence from South America

Umut Oguzoglu

Ashantha Ranasinghe

July 2015 


\title{
Crime and Establishment Size: Evidence from South America
}

\author{
Umut Oguzoglu \\ University of Manitoba \\ and IZA
}

\author{
Ashantha Ranasinghe \\ University of Manitoba
}
Discussion Paper No. 9209
July 2015

\author{
IZA \\ P.O. Box 7240 \\ 53072 Bonn \\ Germany \\ Phone: +49-228-3894-0 \\ Fax: +49-228-3894-180 \\ E-mail: iza@iza.org
}

\begin{abstract}
Any opinions expressed here are those of the author(s) and not those of IZA. Research published in this series may include views on policy, but the institute itself takes no institutional policy positions. The IZA research network is committed to the IZA Guiding Principles of Research Integrity.

The Institute for the Study of Labor (IZA) in Bonn is a local and virtual international research center and a place of communication between science, politics and business. IZA is an independent nonprofit organization supported by Deutsche Post Foundation. The center is associated with the University of Bonn and offers a stimulating research environment through its international network, workshops and conferences, data service, project support, research visits and doctoral program. IZA engages in (i) original and internationally competitive research in all fields of labor economics, (ii) development of policy concepts, and (iii) dissemination of research results and concepts to the interested public.
\end{abstract}

IZA Discussion Papers often represent preliminary work and are circulated to encourage discussion. Citation of such a paper should account for its provisional character. A revised version may be available directly from the author. 
IZA Discussion Paper No. 9209

July 2015

\section{ABSTRACT}

\section{Crime and Establishment Size: Evidence from South America*}

Establishment exposure to crime is a frequent occurrence and a major obstacle to business operation in developing economies. We present a simple theory for the frequency and severity of crime across establishment size that is validated against the data in South America. We find that high expectation of crime at the establishment- level is strongly associated with lower sales, labor and capital investment, and consistent with our theory is most evident among medium size establishments. We consider a variety of specifications that are tenable with a causal interpretation of our results. Moreover, when evaluated relative to a host of distortions emphasized in the literature, crime remains important for explaining establishment size and addressing it may be one of the more important policy reforms for spurring development in South America.

JEL Classification: $\quad 01, \mathrm{O} 4, \mathrm{D} 2$

Keywords: crime, establishment size, misallocation

Corresponding author:

Umut Oguzoglu

Department of Economics

University of Manitoba

647 Fletcher Argue

R3T 5V5 Winnipeg, MB

Canada

E-mail: umut.oguzoglu@umanitoba.ca

\footnotetext{
* We thank Josh Lewis, Pedro Bento, Wayne Simpson, Trevor Tombe, Julia Witt and seminar participants at Dalhousie University for helpful comments and suggestions. All errors are our own.
} 


\section{Introduction}

At least since the pioneering work of Becker (1968), economists have studied the effects of crime on the broader economy within an rational-agent(s) framework. A diverse literature has emerged with a variety of questions examining cross-country or city-level differences in crime, selection into criminal activity and its broader social effects. ${ }^{1}$ However, there is limited evidence for how crime, specifically the exposure to it, affects establishment-level behaviour. In particular, does crime affect decisions related to production, and are there differential effects across the size distribution of establishments? Our focus is to provide evidence for these effects, specifically in relation to inputs in production, output and their differential effects across establishment size using micro-level data.

We emphasize crime because it is highly prevalent in many developing countries, particularly in South America. According to the Enterprise Surveys over 40 percent of establishments in South America report crime is a major obstacle to business operation, which is higher than those who report access to finance, practices of the informal sector or tax administration are major obstacles. There is also considerable heterogeneity in establishment exposure to crime and related losses, both across and within countries in South America. For instance, in Brazil close to 40 percent of establishments report at least one incident related to crime in the previous year and average losses are about 7 percent of annual sales. The corresponding values in Colombia are 29 and 1.1 percent. We think the prevalence of crime should have important implications for factors used in production since establishments have incentives to operate on a smaller scale and invest less (Svensson, 1998). Our goal is to provide a simple framework to analyze these effects and estimate the importance of crime on measures related to establishment size.

Our theory incorporates a channel for crime into an otherwise standard framework of

\footnotetext{
${ }^{1}$ Selected examples include Glaser et al. (1996) who studies the social interactions of crime, Di Tella and Schargrodsky (2004) study the role of policing on crime, Dell (2015) examines drug trade related violence and Munyo (2015) studies selection into crime at the juvenile life-cycle stage. Related to cross-country studies of crime see Fajnzylber et al. (1998), Miron (2001) and related to corruption see Treisman (2000).
} 
heterogeneous establishments that differ in productivity. Establishments use capital in production and face an endogenous probability that a fraction of capital is lost due to crime. Those that use more capital in production are a bigger target for crime, however, they can lower its probability by spending on private protection. Our theory predicts the fraction of capital lost due to crime is hump-shaped in establishment size/productivity. Put differently, mid-size establishments are more vulnerable to crime than small and large establishments. This is due to the role of private protection. Large establishments use lots of capital in production and find it profitable to spend on protection which lowers the likelihood of crime. In contrast, small establishments face minimal crime because they use little capital in production. Mid-size establishments are not adequately profitable to buy sufficient protection and lose the most from crime. Differences in the potential for crime generate heterogeneous responses in production whereby establishments strategically under-produce to minimize losses from crime. Our simple theory generates three testable predictions that can be validated empirically: 1) high potential for crime lowers inputs in production and establishment output, 2) spending on protection rises with establishment size and 3) crime is most prevalent in lowering inputs/production among mid-size establishments.

To test our theory we focus on countries in South America and use the World Bank Enterprise Surveys, which contains micro-level data on establishment production and other relevant characteristics. Also included are obstacles to business operation, including information related to crime - whether the establishment experienced crime in the past year and losses attributed to it - and spending on private protection (security). ${ }^{2}$ The dataset also includes establishment responses to whether crime, theft and disorder is an obstacle to business operation, which we refer to as crime expectation. This is particularly relevant for our analysis because measures related to establishment size and losses from crime are co-dependant variables determined within the model. An implication is that using losses from crime in our empirical framework will generate biased estimates. We instead use crime expectation,

\footnotetext{
${ }^{2}$ To be clear, establishments report whether they experienced incidents related to arson, robbery, theft or vandalism, which we interpret as crime.
} 
which reflects an establishment's belief or perception of the severity of crime on business operation, to estimate its effects on establishment size. In fact, crime expectation works well for our analysis because it can capture an establishment's strategic response to crime that actual losses from crime fail to account for: an establishment may lower production if they anticipate substantial losses from crime even though they may not subsequently face crime.

We find, establishments that report high crime expectation are associated with higher spending on protection and have lower sales, labor and capital investment. For instance, when including country, city, industry and establishment specific controls, establishments that have high crime expectation are associated with 20 percent lower sales, 13 percent fewer employees and 10 percent lower capital investment. We also evaluate the differential effects of crime expectation across small, medium and large establishments. Consistent with our theory, medium size establishments are most burdened by crime. Our estimates imply that medium size establishments who report high crime expectation hire 7 percent fewer employees and have 30 percent lower sales relative to medium size establishments that do not report high crime expectation. Corresponding results for small and large establishments are not statistically significant.

We also consider several specifications of our framework that are more tenable to a causal interpretation of our results. First, we re-estimate the effects of crime expectation among establishments that did and did not face crime separately, to verify if crime expectation and its effects on size are influenced by current losses from crime. We find that crime expectation remains negatively associated with sales, labor and capital even among establishments that did not face crime. Second, using panel data we estimate the effects of lagged crime expectation on current establishment outcomes. The motivation underlying this strategy is that lagged crime expectation has a one-directional interpretation: it can affect current decisions related to production, but current decisions have no potential to influence expectations from a previous period. Third, we employ an instrumental variable approach using average crime expectation within industry, city and country as an instrument for crime expectation. Our 
results have a plausibly causal effect if average crime expectation affects size only through its effects on establishment-level crime expectation. In all specifications we obtain estimates that are overwhelmingly consistent with our story: establishments that have high crime expectation have lower sales, labor and capital investment.

This paper relates to the literature that emphasizes the allocation of resources is important for understanding establishment size and productivity differences in poor countries (Banerjee and Duflo, 2005; Restuccia and Rogerson, 2008; Guner et al 2008; Hsieh and Klenow, 2009 and Bartelsman et al. 2013). We highlight the importance of crime as a mechanism for understanding these differences. Moreover, we show that establishments may strategically under-produce to avoid losses from crime, which lowers average establishment size in these countries, which is consistent with Bento and Restuccia (2015) who document a clear negative relationship between establishment size and development. Related is Ranasinghe (2014) and Ranasinghe and Restuccia (2015) who study extortion and crime using quantitative macro models that feature heterogeneous producers. Our results are complimentary to theirs, though we use micro-level data to estimate the implied effects of crime on establishment production. Also related is Johnson et al. (2002) who show that weak property rights and expropriation discourage establishment re-investment of profit in their business.

Several other papers in the literature have emphasized access to finance (Buera et al., 2011), the informal sector (La Porta and Shleifer, 2014), corruption (Dusha, forthcoming) and transportation/entry barriers (Adamopoulos, 2011 and Moscoso Boedo and Mukoyama, 2012), as important distortions for understanding establishment under-performance in poor countries. The Enterprise Surveys contain 'expectation' measures, similar to that for crime, related to these distortions also, which enable us to assess their importance relative to crime in South America. Including these distortions as additional controls in our regressions, crime remains an important distortions for explaining establishment size differences, and this is especially evident among mid-size establishments. Our results indicate that lowering crime maybe one of the most pertinent policy prescriptions to foster establishment growth and 
expansion (Johnson et al., 2002).

The paper proceeds as follows. Section 2 provides micro-level evidence related to crime in South America and relative to other distortions. In Section 3 we present a simple model that incorporates a channel for crime and generates testable predictions that we take to the data. Section 4 describes the data in detail and Section 5 outlines our empirical strategy. The effects of crime on establishment outcomes and robustness checks are presented in Section 6 , and Section 7 concludes.

\section{Facts related to crime}

The World Bank Business Environment and Enterprise Performance Survey (BEEPS) contains establishment-level data related to major obstacles businesses face in day to day operations. Included are questions related to crime: its frequency, losses attributed to it (as a percentage of sales and in absolute terms) and a ranking of its severity. We leave the discussion on the particulars of the dataset for a later section and focus here on key facts related to crime at the country-level. While crime related data is available for over 100 countries we restrict attention to crime in South America, where it is most severe and to limit institutional differences in our cross-country comparisons (Brunetti et al., 1997).

Table 1 reports key measures related to establishment-level crime in South America. Column 2 reports the percentage of establishments that report incidences related to arson, robbery, theft or vandalism on their premises in the past year (henceforth crime). This definition of crime is related to criminal activity and not petty crime (for example, theft of workplace stationary). A notable fact from Table 1 is that crime is a frequent occurrence in South America. In most countries, over 35 percent of establishments report at least one incident related to crime in a given year - establishments in Peru report the fewest incidences related to crime (24 percent of surveyed establishments) and establishments in Chile report the most (48 percent). A high frequency of crime however may not imply that it is a severe 
constraint to business operation. To gauge its severity, establishments are asked to rate whether crime is not a problem, a minor problem, a moderate problem, a major or a severe problem. ${ }^{3}$ The third column in Table 1 reports the fraction of establishments that report crime is a major or severe (henceforth major) obstacle to business operation. In most South American countries, well over 30 percent of establishments report crime is a major obstacle to business operation, with values as high as 60 and 70 percent in Venezuela and Brazil. To put these numbers in context, the fraction of establishments that report crime is a major obstacle to business operation in Germany, Korea and Ireland (three developed countries in the dataset) range from 1 to 5 percent. Finally, column 4 reports average losses from crime as a percentage of sales for all establishments and column 5 reports this same statistic among establishments that experienced crime. Losses due to crime are a non-trivial share of sales, especially among those establishments that experience crime. For example, in Ecuador among establishments that are victims of crime, average losses as a percentage of sales is 3.4 percent, and for the country as whole is 1 percent.

Crime is a frequent occurrence, a major obstacle to doing business and a non-trivial share of sales in South America. Next, we ask whether crime is one of the main obstacles for doing business in South America or simply one of the myriad problems that plagues development in this region. Some of the constraints for business performance emphasized in the literature include access to finance, access to licences and permits and functioning of the courts. ${ }^{4}$ The Enterprise Surveys contain data on these obstacles which allow us to assess the severity of crime relative to these obstacles (access to finance, permits and courts). Specifically, and similar to the case for crime, establishments are asked to rate whether access to finance, access to licences and permits, and functioning of courts are a major, moderate, minor or non-obstacle to business operation. Table 2 reports the fraction of establishments that say

\footnotetext{
${ }^{3}$ To be precise, establishments are asked to rate whether crime, theft and disorder is a constraint to doing business. We interpret this question as primarily related to crime since it follows immediately after questions pertaining to crime in the survey.

${ }^{4}$ See for example Banerjee and Duflo (2005) and Restuccia and Rogerson (2008) for a broad discussion related to the obstacles to doing business. See Buera et al., (2011), Midrigan and Xu (2014), Mosco-Boedo and Mukoyama (2009), and Guner et al. (2008) for a macro perspective arising from these business obstacles.
} 
Table 1: Crime across South American Countries

\begin{tabular}{lcccc}
\hline \hline Country & $\begin{array}{c}\text { Incidence of crime } \\
\text { (\% of establishments) }\end{array}$ & $\begin{array}{c}\text { Major obstacle } \\
\text { (\% of establishments) }\end{array}$ & $\begin{array}{c}\text { Avg. losses } \\
\text { (\% of sales) }\end{array}$ & $\begin{array}{c}\text { Avg. losses (if > 0) } \\
\text { (\% of sales) }\end{array}$ \\
\hline Argentina & 33 & 29 & 0.6 & 2.0 \\
Bolivia & 31 & 45 & 0.8 & 3.5 \\
Brazil & 38 & 69 & 2.5 & 6.9 \\
Chile & 48 & 38 & 0.8 & 1.7 \\
Colombia & 29 & 33 & 0.3 & 1.1 \\
Ecuador & 31 & 35 & 1.0 & 3.4 \\
Guyana & 43 & 36 & 1.0 & 2.5 \\
Paraguay & 39 & 37 & 1.3 & 3.7 \\
Peru & 24 & 28 & 0.6 & 2.8 \\
Uruguay & 38 & 35 & 0.3 & 1.1 \\
Venezuela & 44 & 59 & 1.4 & 3.6 \\
\hline \hline
\end{tabular}

The second through fifth columns report the percentage of establishments that report incidences related to crime in the past year, the percentage of establishments that report crime is a major obstacle to business operation and average losses due to crime as percentage of sales (among all establishments and contingent on facing crime). All country statistics are from 2010 except for Brazil which is from 2009 (BEEPS, World Bank).

a given distortion is a major obstacle to business operation. In South America a substantial percentage of establishments report access to finance, licences and permits and functioning of courts are major obstacles to business operation. However, more establishments report crime is major obstacle than either of these in 7 of the 11 countries listed. These descriptive statistics suggest that crime maybe one of the more important distortions for understanding establishment (under)performance in South America.

We also examine two often cited constraints to business performance in developing countries: tax rates and corruption (not reported in Table 2). As a major obstacle to doing business, crime is on par with tax rates. In fact, in 6 of the 11 countries, more establishments report crime is a major obstacle to business operation than those who report tax rates are. Corruption, however, appears to be one of the biggest obstacles in South America. In 8 of the 11 countries, more establishments list corruption as a major obstacle than crime. Nonetheless, we view crime as one of the features underlying corruption and as the preceding tables show, crime is one of the major obstacles to business performance.

Given its severity in South America we consider how crime can affect business perfor- 
Table 2: Major obstacles to doing business

\begin{tabular}{lcccc}
\hline \hline & \multicolumn{4}{c}{ (percentage of establishments) } \\
Country & Crime & Finance & Permits & Courts \\
\hline Argentina & 29 & 44 & 21 & 44 \\
Bolivia & 45 & 29 & 13 & 35 \\
Brazil & 69 & 45 & 48 & 45 \\
Chile & 38 & 18 & 8 & 13 \\
Colombia & 33 & 41 & 11 & 24 \\
Ecuador & 35 & 19 & 18 & 42 \\
Guyana & 36 & 18 & 13 & 22 \\
Paraguay & 37 & 20 & 23 & 27 \\
Peru & 28 & 9 & 20 & 29 \\
Uruguay & 35 & 16 & 8 & 12 \\
Venezuela & 59 & 9 & 23 & 30 \\
\hline \hline
\end{tabular}

This Table reports the percentage of establishments that report whether crime, access to finance, obtaining business licences and permits, and the functioning of the court system are major obstacles to business operation.

mance. According to the data, not all establishments face crime and for those that do, losses attributed to crime varies considerably across and within countries. Our focus is to examine the affects of crime on establishment size and whether there exists systematic patterns across size. In particular, does the probability of facing crime and losses attributed to it vary across size, and how does this affect establishment production and its implications for understanding resource misallocation? The micro-level data related to crime in the Enterprise Surveys are ideal for analyzing these effects. We begin by presenting a simple theory of crime related establishment size that will guide our empirical analysis.

\section{Model}

We consider an otherwise standard model of heterogeneous establishments/producers and incorporate a channel for crime as in Ranasinghe (2014). In our framework, establishment production is influenced by expected losses from crime. Decisions facing an establishment is presented first, followed by the decision of an exogenous group (mafia) that expropriates capital from an establishment (crime). We focus on a static setting as it more naturally 
relates to the empirical analysis that follows. Moreover, we assume perfectly competitive markets and introduce crime as the only source of friction in the economy to highlight the importance of this channel.

\subsection{Environment}

Establishments have heterogenous productivity $s \in S$, and produce a homogeneous final good $y$. Production technology is standard: $y=s k^{\alpha}, 0<\alpha<1$, where $k$ is capital used in production and $y$ is output. We abstract from labor for simplicity. Differences in productivity are to capture the efficiency of establishments and/or demand for its goods. Since productivity is complimentary in production it implies that capital and output increase with productivity.

Next, we allow for the possibility that a fraction of establishment capital is lost due to crime (expropriated by the mafia). There are two factors that affect the likelihood an establishment faces crime: 1) an exogenous level of property rights - related to legal institutions

and rule of law - that is common across establishments within an economy, and 2) establishment spending on private protection. We take the stance that stronger property rights and protection expenditure reduce the likelihood of crime. Specifically, an establishment faces crime with probability $1-F(\lambda, p) \in(0,1)$, where $\lambda$ is a measure of property rights and $p$ is establishment-level protection. When $F(\lambda, p)=1$, which can occur if property rights are very strong and/or if an establishment invests in sufficient protection, there is no potential for crime. In what follows, we assume a functional form for $F(\lambda, p)$ that is increasing in both arguments.

\subsection{Crime and Establishment decisions}

The problem of an establishment is to choose capital and protection to maximize profit. The mafia observes these decisions and chooses a fraction of capital to expropriate (details to follow). Timing wise, an establishment moves first followed by the mafia. Therefore, 
establishment decisions related to production and protection are influenced by expected losses from crime, or put differently, in anticipation of the mafia's best-response to its choices. Let $\pi(s, k)=s k^{\alpha}-r k$ and $\pi_{e}(s, k)=s k^{\alpha}-(r+e) k$ represent establishment profit when it does not and does face crime, where $r$ is the rental cost of capital and $e \in(0,1)$ is the fraction of capital lost due to crime. ${ }^{5}$ An establishment with productivity $s$ chooses capital and protection to maximize expected profit in the following way:

$$
\begin{aligned}
\tilde{\pi}(s) & =\max _{k \geq 0, p \geq 0} F(\lambda, p) \pi(s, k)+(1-F(\lambda, p))(1-e) \pi_{e}(s, k)-c_{p}(p), \\
& =\max _{k \geq 0, p \geq 0} \pi(s, k)-(1-F(\lambda, p)) e k-c_{p}(p) .
\end{aligned}
$$

Equation (1) states that with probability $F(\lambda, p)$ the establishment does not face crime and earns its full profit from production $\pi(s, k)$, and with probability $1-F(\lambda, p)$ faces crime and earns $\pi_{e}(s, k) \cdot c_{p}(p)$ is the cost of buying protection which is increasing in $p .{ }^{6}$ This expression simplifies to imply the establishment earns its entire profit from production less the fraction of capital lost due to crime $e k$, which occurs with probability $1-F(\lambda, p)$. When property rights are perfect such that $F(\lambda, p)=1$ (or if an establishment buys lots of protection) there is no opportunity for crime. In this instance, the problem of an establishment becomes a standard one of choosing capital to maximize profit, the first-best scenario.

Next, we describe the decision of the mafia. For simplicity we assume a stand-in mafia with monopoly power that can expropriate capital from establishments. ${ }^{7}$ The mafia has full information concerning establishment capital and protection, and optimizes by choosing how

\footnotetext{
${ }^{5}$ Crime serves as an additional cost to capital since a fraction of capital is stolen after production has taken place; $\pi_{e}(s, k)=s k^{\alpha}-(1+r) k+k(1-e)$. When $e=0, \pi_{e}(s, k)=\pi(s, k)$. We have also worked-out a version of the model where crime is on establishment output instead of inputs in production. The central implications of the model are consistent under either specification.

${ }^{6}$ Protection expenditure is related to items such as surveillance, monitoring equipment and guards. In our framework this reduces the potential of crime and is independent of establishment capital. In the equilibrium of the model, protection expenditure is increasing in establishment size (capital).

${ }^{7}$ Typically, there may be multiple groups that engage in establishment-level crime within a region, especially activities related to robbery and vandalism. For our purposes, and in particular the empirical analysis that follows, what matters are establishment (expected) losses from crime and not its source, which allows us to abstract to a stand-in mafia.
} 
much to expropriate from each establishment. ${ }^{8}$ Specifically, the problem for the mafia is

$$
\Pi_{M}(s)=\max _{e \geq 0}(1-F(\lambda, p)) e k-c_{e}(e)
$$

The expression in (2) accounts for the fact the mafia expropriates an amount $e k$ from an establishment which occurs with probability $1-F(\lambda, p)$. Crime is unsuccessful with probability $F(\lambda, p)$ and has a return equal to zero. $c_{e}(e)$ is the cost associated with crime which is increasing in $e$ - to steal/damage a higher fraction of capital, more resources must be spent by the mafia to successfully complete the task. Based on (2), establishments that use more capital in production are a more lucrative target for crime, however, increasing protection expenditure makes it less likely the mafia is successful in expropriating capital. Understanding the trade-offs between crime, protection and capital demand, and how it varies across size is a topic we discuss in the following sub-section.

We can now discuss the partial equilibrium implications for establishment-level production. Solving (1), and taking crime and protection as given, optimal capital and production are

$$
\begin{aligned}
& k^{*}(s)=\left(\frac{\alpha s}{r+(1-F(\lambda, p)) e}\right)^{\frac{1}{1-\alpha}} \\
& y^{*}(s)=\left(\frac{\alpha s}{r+(1-F(\lambda, p)) e}\right)^{\frac{\alpha}{1-\alpha}} .
\end{aligned}
$$

Capital and production decisions are the standard, first-best values except for $h \equiv(1-F(\lambda, p)) e$, a term which captures anticipated or expected losses from crime. Since we assume a functional form for $F(\lambda, p)$ that is increasing in both arguments, our theory makes two key predictions:

(i) $\frac{d k}{d h} \leq 0$ : establishment capital demand falls with expected losses from crime.

(ii) $\frac{d k}{d p} \geq 0$ : high capital establishments spend more on protection.

These predictions are analogous for establishment output. In our empirical analysis we

\footnotetext{
${ }^{8}$ This is not in the literal sense but rather to capture that criminal organizations can gauge the approximate value of items that can be stolen from an establishment, as well the difficulty in successfully doing so.
} 
test the validity of these predictions and pay particular attention to prediction (i), which highlights the emphasis of the paper: the effects of crime on establishment size, specifically in relation to output and inputs used in production. Importantly, expected losses from crime will vary across establishments within and across countries; within countries due to differences in protection expenditure $(p)$ and across countries due to differences in property rights $(\lambda)$. Our focus is estimate the importance of crime on measures related to establishment size accounting for these considerations.

\subsection{Equilibrium}

We now examine the equilibrium implications of the model. To this end, we take a stance on the functional forms for $F(\lambda, p)$, the cost of buying protection $c_{p}(p)$ and the mafia's cost function for crime $c_{e}(e)$. We assume that $F(\lambda, p)=\lambda+\lambda p^{\theta}$, where $\theta>0$ and $p \in[0, \bar{p}]$ with $\bar{p} \equiv\left(\frac{1-\lambda}{\lambda}\right)^{\frac{1}{\theta}}$. This implies that protection and property rights reduce the likelihood of crime, are complimentary and the probability of facing crime is at most $1-\lambda .{ }^{9}$ For the cost functions, we assume $c_{p}(p)=b p^{\psi} / \psi$ and $c_{e}(e)=a e^{\rho} / \rho$ with $b, \psi, a, \rho>0$. Setting the values of $b=\rho=\psi=2$, the equilibrium solutions for protection and crime, for any choice of capital, are equal to ${ }^{10}$

$$
p=\frac{\lambda(1-\lambda) k^{2}}{a+\lambda^{2} k^{2}}, \quad e=\frac{(1-\lambda) k}{a+\lambda^{2} k^{2}}
$$

We note that $k$ depends on establishment productivity $s$, which implies $p$ and $e$ also depend on productivity.

\footnotetext{
${ }^{9}$ We implicitly think of $\lambda$ as a probability with which the state can prevent crime. Countries that have stronger property rights have higher $\lambda$ 's and are better are preventing crime. Noting that $\bar{p}=\left(\frac{1-\lambda}{\lambda}\right)^{\frac{1}{\theta}}$, $F(1, p)=1$ and $F(0, p)=0$. Based on our complimentarily assumption this implies when property rights are perfect $(\lambda=1)$, protection is not required and when property rights are non-existent $(\lambda=0)$, protection is ineffective towards reducing crime.

${ }^{10}$ In fact, as long as $\psi>0, \rho>1$ and $\theta=\frac{\psi(\rho-1)}{\rho}$, the predictions that follow hold for any specification of parameter values. We focus on $b=\rho=\psi=2$ because it simplifies the solutions without altering anything central to the model. See Ranasinghe (2014) for a discussion on the sensitivity of the analytical results from alternate cost functions for crime and protection.
} 
Differentiating these expressions with respect to capital implies that protection is rising with $k$ in equilibrium (larger establishments spend more on protection), and the fraction of capital lost due to crime $e$, is 'hump-shaped' in $k$. Note also that because capital rises with productivity, it follows that $p$ also rises with $s$ and $e$ is hump-shaped in $s$. The latter is particularly relevant because it implies losses from crime are non-linear in establishment size. According to our theory large establishments spend lots on protection which reduces the likelihood of crime and thus potential losses, and small establishments experience limited losses from crime because they do not have much capital to steal. Mid-size establishments are the more lucrative targets for the mafia: they use sufficient capital in production to warrant crime yet are not sufficiently profitable to spend on adequate protection to reduce the likelihood of crime.

Using these insights we can evaluate how expected losses $(h \equiv(1-F(\lambda, p)) e)$ varies across establishment size (capital), and across economies that differ in property rights. As depicted in Figure 1, expected losses from crime are 'hump-shaped' in productivity (and capital) and expand outward as property rights fall. Importantly, in countries where property rights are weak, mid-size establishments have a higher expectation of crime than small and large establishments, and are therefore most affected by crime.

We can also use our solutions for crime and protection to understand its effects on capital misallocation. Substituting the expressions in (5) into (1) and differentiating with respect to capital generates an expression for optimal capital demand

$$
M P K=r+\xi(\lambda, k)
$$

where $M P K$ is the marginal product of capital and $\xi(\lambda, k)=\frac{2 a(1-\lambda)^{2} k}{\left(a+\lambda^{2} k^{2}\right)^{2}} \geq 0$. When $\lambda=1$ or $k$ is extremely large, $\xi(\lambda, k)=0$ and we have the first-best outcome where capital is chosen where the $M P K=r$. When $\lambda<1$ (i.e. an environment where crime is possible) $\xi(\lambda, k)$ is positive and hump-shaped in capital implying that establishments choose capital below optimal capacity (since $M P K$ is higher), and this is especially prominent among mid- 


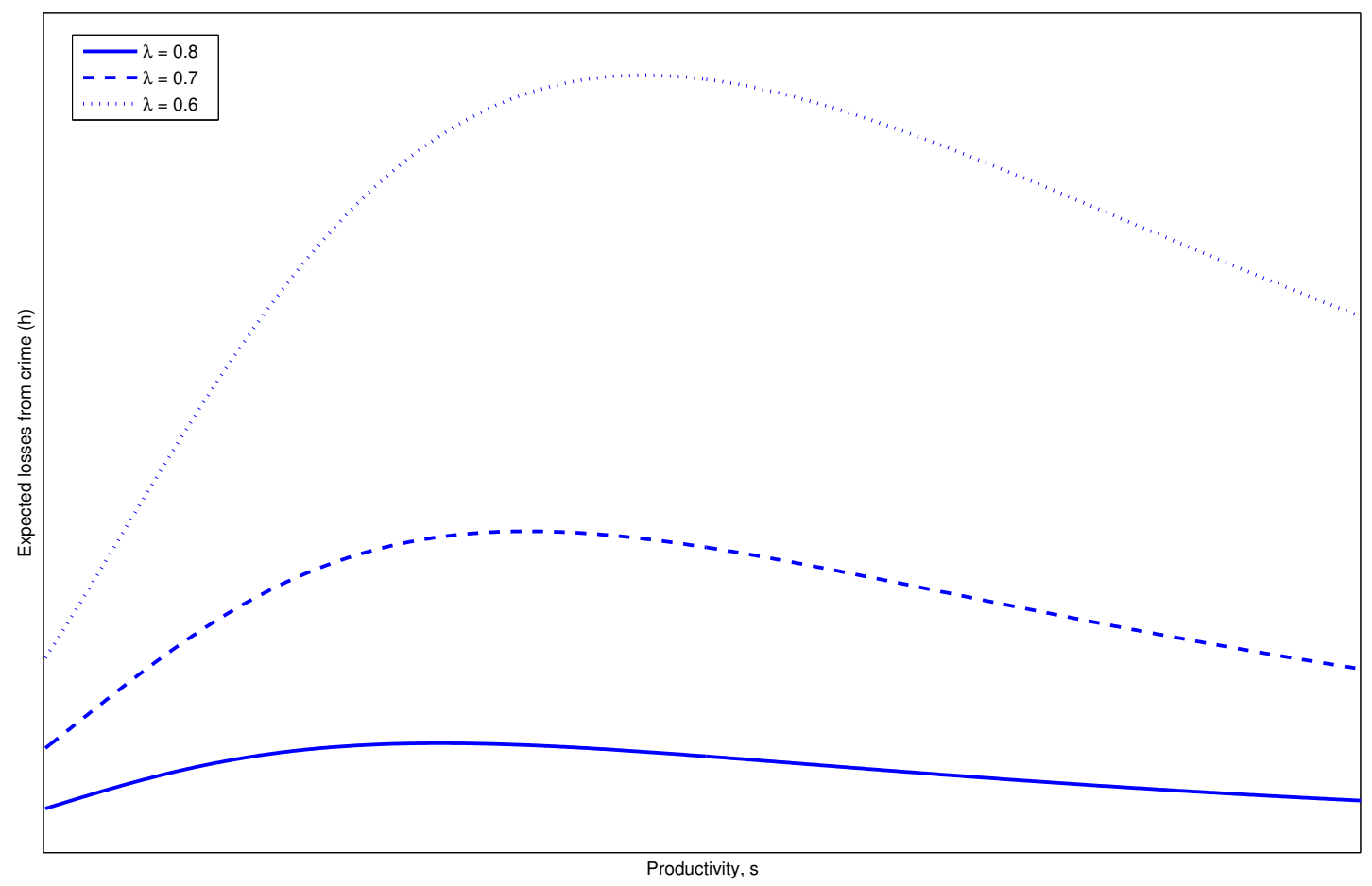

Figure 1: Expected losses from Crime

size establishments. Put differently, establishments that anticipate significant losses from crime operate on a smaller scale to mitigate losses and this is most prevalent among mid-size establishments. We evaluate the validity of these predictions in what follows.

\section{Data}

The data we use is from the World Bank Business Environment and Enterprise Surveys (BEEPS). The data is collected via face-to-face interviews, typically with the manager, to understand the major obstacles establishments face in day-to-day operation. A convenient feature is the survey is administered in a similar form within continents which allows for cross-country comparisons. We restrict our empirical analysis to countries in South America to limit variation in institutional and cultural differences, and because crime is most prevalent 
in this region. The initial rollout of the survey was conducted in 2003 with subsequent and more complete rollouts conducted within a three-to-four year span. To be comparable across countries we use 2010 survey with the exception of Brazil which is from 2009 survey. The BEEPS also provide longitudinal information for a sub-sample of firms within a country. We exploit this feature for robustness by using panel data between 2003 and 2009 for Brazil, and panel data between 2006 and 2010 for all other countries in our sample.

The dataset includes establishments in manufacturing, service and other sectors (mostly construction and transport). The manufacturing sector accounts for over 70 percent of establishments and the service sector accounts for more than 20 percent. About 85 percent of businesses are stand-alone (i.e. do not belong to a larger establishment). The dataset includes general information related to the establishment (legal status, year it was formed), questions related to production and operation costs (sales, employees, capital) as well as specific questions related to distortions they face (access to licences, electricity, bank loans). We exclude establishments from our sample who do not report values for sales, those who were deemed untruthful in their responses, as well as establishments above the 99th percentile for sales, labor, capital and protection expenditure, by country. In total we are left with over 6000 establishments in our sample for 2010: Argentina (792), Bolivia (167), Brazil (1523), Chile (875), Colombia (774), Ecuador (301), Paraguay (263), Peru (842), Uruguay (386) and Venezuela (153).

For the empirical analysis that follows we require information related to measures of establishment size, proxies for productivity, country-level controls, and information related to crime. For measures related to size, we focus on establishment-level sales, labor (annual cost of labor and/or number of full-time employees), capital investment and protection spending. ${ }^{11}$ We also have general information related to the establishment including the top manager's experience in the industry, number of employees when established, registration status (sole

\footnotetext{
${ }^{11}$ For capital investment we use the sum of annual expenditure on machinery, vehicles and equipment, and annual expenditure on land and buildings. We account for land and building expenditure because they signal profitability and are subject to acts of arson or vandalism. For protection, we know which establishments spend on protection and the share of sales it accounts for.
} 
proprietorship, partnership, privately or publicly held) and whether the establishment is a stand-alone enterprise or part of a larger firm. We use these characteristics as proxies for establishment-level productivity. Also included are close to 30 classifications for industry ranging from food, textiles, chemicals, construction (manufacturing related industries) to retail, hotels, restaurants and information technology (more service oriented industries). We also know the characteristic of a city an establishment operates in - whether a capital city, and if not, the approximate population size: < 50, $50-250,250-1000$ and $>1000$, in thousands. We use information on industry and city as additional controls.

As already noted, establishments are asked if they experienced losses as a result of theft, robbery, vandalism or arson - which we refer to as crime - and approximate losses it accounts for as percentage of annual sales or in total value. Establishments also report whether crime, theft and disorder are a non-obstacle, minor, moderate, major or severe obstacle to current business operations. Hence, we know whether an establishment faced crime, losses it accounts for and a ranking of its severity.

A further convenience of the dataset is that it includes a variety of questions related to distortions establishments encounter. In particular, whether practices of competitors in the informal sector, functioning of courts, transportation and access to finance are obstacles to business performance. We use this information in what follows to measure the importance of crime, net of these distortions.

\section{Empirical strategy}

Two central predictions from the model presented in Section 3 are that crime prompts establishments to operate on a smaller scale and its severity varies across establishment size. We now introduce our empirical specification to test this theory. Our estimating equations are versions of (3) and (4) which imply inputs in production and output are positively related 
to protection spending and productivity specific factors, and negatively related to crime. ${ }^{12}$ We focus on four dependant variables related to establishment size: sales, number of employees, capital investment (henceforth capital) and protection spending. The independent variable of interest is related to crime. While data on establishment-level losses from crime are available, the model presented in Section 3 implies output, capital, protection and crime are endogenous outcomes. Current period losses from crime depend on establishment capital, in which the latter already accounts for - or is chosen in anticipation of - expected losses from crime.

To estimate the effects of crime on establishment size a measure for expectation of crime, or alternatively, anticipated losses from crime is required. As noted earlier, establishments report whether crime is not an obstacle, a minor, moderate, major or severe obstacle to business operation - an assessment of the severity of crime on their business - which reflects an establishment's expectation of crime (crime expectation). While crime expectation does not directly capture anticipated losses from crime, it does capture an establishment's belief or expectation of the degree to which crime affects business operation, and is therefore informative of the effects of crime on measures related to establishment size. In fact, crime expectation works well for our purposes because it captures an establishment's belief regarding the severity of crime irrespective of whether they have faced crime, thereby allowing us to capture the full effect of crime on establishment outcomes. ${ }^{13}$ Our estimation approach is based on the premise that crime expectation affects decisions related to production, in which these production decisions subsequently affect the potential for crime.

We define crime expectation as an indicator-variable, equal to one if an establishment reports crime is a major or severe obstacle to business operation (high crime expectation) and zero otherwise (low crime expectation). We also consider a version where crime expectation

\footnotetext{
${ }^{12}$ For simplicity, capital is the only input in the model and is subject to crime. Other inputs, say labor, will be affected by crime if inputs in are complimentary in production.

${ }^{13}$ For instance, an establishment may reduce capital (or other inputs) if they anticipate a high likelihood of crime (crime expectation) even though they may not subsequently face crime. Crime expectation is therefore ideal because it captures establishment strategic responses to crime that actual losses from crime fail to account for.
} 
is a continuous measure taking five possible values (from not an obstacle to severe obstacle). Our estimating equation is

$$
\ln \left(y_{i j k}\right)=\beta_{1} s_{i j k}+\beta_{2} c e_{i j k}+X_{j}+Z_{k}+\epsilon_{i j k}
$$

where $y_{i j k}$ is an outcome of interest - establishment sales, labor, capital or protection spending - for establishment $i$ in country $j$ in industry $k, s_{i j k}$ are establishment specific characteristics related productivity, $c e_{i j k}$ is an indicator for establishment crime expectation, $X_{j}$ are countrylevel fixed effects and $Z_{k}$ are industry-level fixed effects. The variable of interest is $c e_{i j k}$. Based on the model we expect $\beta_{2}$ is negative - that is to say, all else equal, establishments that have high crime expectation operate on a smaller scale - and in particular, that $\beta_{2}$ has a larger negative value for mid-size establishments than small and large establishments. We control for industry-level effects since they affect scale of operation and because crime can be particular to select industries. Similarly, we also control for city characteristics (categories for population size and whether a capital city) since crime may be prevalent to particular regions within countries.

A concern about our estimation approach is whether crime expectation is influenced by current losses from crime, which would bias our results. In the data, the correlation between crime expectation and whether an establishment experienced crime is 0.16 , and the correlation between crime expectation and losses attributed to crime is 0.06 . This is suggestive evidence that an establishment's expectation of crime maybe driven by other factors - for instance, friends/family experiences with crime, media coverage, cultural norms - and to a lesser extent by current period losses from crime. In this case $c e_{i j k}$ serves as a reasonable proxy to measure the effects of crime on establishment size.

While the above framework serves as our main empirical framework, we recognize the potential that crime expectation may not be entirely exogenous and can be influenced by factors related to establishment size. To account for these concerns and provide a plausibly casual interpretation our results we consider several robustness checks. First, we re-estimate the 
effects of crime expectation among establishments that did not face crime, thereby ensuring that crime expectation is not influenced by current losses from crime. Second, we estimate the effects of lagged crime expectation on establishment outcome variables. Specifically, we use panel data for years 2006 and 2010 (though it comes at the cost of sample size) to estimate the effect of establishment crime expectation in 2006 on outcome variables in 2010. The underlying motivation is that crime expectation in 2006 can be influenced by crime in that year but not by establishment-level crime in 2010. By using lagged crime expectation as a regressor we are estimating the effect of crime expectation from a previous period on current establishment outcomes. We also explore an instrumental variable strategy using average crime expectation within industry, city and country to instrument establishment-level crime expectation. In all, we view our primary specification together with these robustness checks as providing evidence for the effects of crime on measures related to establishment size.

Before discussing our results, it is worth noting that crime expectation is a subjective measure and prone to its typical limitations. However, this measure is based on manager responses and should be more in-line within a rational-agent framework than standard household surveys that include subjective measures. Moreover, relevant for our analysis is whether crime expectation affects establishment behaviour, whether real or imagined. Also worth noting is that managers play a central role guiding establishment performance (Bloom and Van Reenen, 2007; Bloom et al. 2013). It is possible that managers who report high crime expectation may be lower quality managers and the effects of crime expectation on measures related to establishment size could be driven by weak management. For instance, a low quality manager might report high crime expectation to justify poor performance, or alternatively, not fully understand the environment and over or understate the severity of crime. In our regressions we attempt to control for this by including the top manager's experience in the industry as a proxy for manager ability (Toth, 2014). ${ }^{14}$ Hence, our estimates for crime

\footnotetext{
${ }^{14}$ Ideally, we would have focused on managers who are present in both panels and differenced-out manager fixed effects. Unfortunately, it is not possible to identify managers in the surveys. We considered a version where we assumed the same manager across panels if years of experience increased by the number of years between the panels (i.e. if manager experience is 5 years in 2006, then we assume it is the same manager in
} 
expectation are after accounting for managerial quality differences.

\section{$6 \quad$ Results}

We begin by presenting results for crime expectation on measures related to establishment size. We then compare the effects of crime expectation relative to other establishment-level obstacles to business operation. In particular, we focus on access to finance, tax administration/rates and practises of the informal sector to evaluate the importance of crime on establishment size relative to these distortions in South America. Finally, to address issues related to endogeneity, particularly that crime expectation maybe influenced by current losses from crime, we consider several robustness checks to validate and provide a plausibly casual interpretation of our results.

\subsection{Effects of crime expectation}

Table 3 reports estimates of crime expectation, coefficient $\beta_{2}$ from equation 7. Reported are effects of crime expectation on four dependant variables related to establishment size: sales, labor (number of full-time employees), capital and protection spending, all in logs. ${ }^{15}$ In column 1 we include only country fixed effects; in column 2 we add industry and city fixed effects and in column 3 we add establishment specific controls for productivity.

The point estimates of crime expectation on establishment sales, labor and capital are negative and significant. Based on columns $1-3$ crime expectation is associated with a reduction in sales in the range of $25-30$ percent, a reduction in employees in the range of 13-18 percent and a reduction in capital in the range of 10-18 percent (though the coefficient for capital in column 3 is not significant). ${ }^{16}$ That is to say, on average, establishments

2010 if experience is 9 years). However, we were left with fewer than 200 observations across all countries under this approach and chose not to pursue it.

${ }^{15}$ We also evaluate the annual cost of labor (which can account for quality of the labor force) as a dependant variable. We do not report results for this variable because they are similar to the coefficients we obtain for sales.

${ }^{16}$ The estimating equation is semi-log which implies the magnitude of the coefficient is interpreted as 
Table 3: Effect of crime on establishment outcomes

\begin{tabular}{|c|c|c|c|c|}
\hline & (1) & $(2)$ & $(3)$ & $(4)$ \\
\hline \multicolumn{5}{|l|}{ Dependant: sales $(\log s)$} \\
\hline Crime expectation & $\begin{array}{c}-0.350^{* * *} \\
(0.0634)\end{array}$ & $\begin{array}{c}-0.338^{* * *} \\
(0.0627)\end{array}$ & $\begin{array}{c}-0.290^{* * *} \\
(0.0593)\end{array}$ & $\begin{array}{c}-0.057^{* * *} \\
(0.0212)\end{array}$ \\
\hline Observations & 6076 & 6076 & 6076 & 6076 \\
\hline \multicolumn{5}{|l|}{ Dependant: labor (logs) } \\
\hline Crime expectation & $\begin{array}{c}-0.203^{* * *} \\
(0.0358)\end{array}$ & $\begin{array}{c}-0.182^{* * *} \\
(0.0354)\end{array}$ & $\begin{array}{c}-0.146^{* * *} \\
(0.0318)\end{array}$ & $\begin{array}{c}-0.023^{* *} \\
(0.0115)\end{array}$ \\
\hline Observations & 6075 & 6075 & 6075 & 6075 \\
\hline \multicolumn{5}{|l|}{ Dependant: capital (logs) } \\
\hline Crime expectation & $\begin{array}{c}-0.204^{* *} \\
(0.0793)\end{array}$ & $\begin{array}{c}-0.165^{* *} \\
(0.0788)\end{array}$ & $\begin{array}{c}-0.114 \\
(0.0761)\end{array}$ & $\begin{array}{c}-0.031 \\
(0.0279)\end{array}$ \\
\hline Observations & 3841 & 3841 & 3841 & 3841 \\
\hline \multicolumn{5}{|l|}{ Dependant: protection (logs) } \\
\hline Crime expectation & $\begin{array}{c}-0.002 \\
(0.0903)\end{array}$ & $\begin{array}{c}0.008 \\
(0.0894)\end{array}$ & $\begin{array}{c}0.073 \\
(0.0860)\end{array}$ & $\begin{array}{c}0.061^{*} \\
(0.0311)\end{array}$ \\
\hline Observations & 3841 & 3841 & 3841 & 3841 \\
\hline Country-level controls & Y & $\mathrm{Y}$ & $\mathrm{Y}$ & $\mathrm{Y}$ \\
\hline Industry \& city level controls & $\mathrm{N}$ & $\mathrm{Y}$ & Y & $\mathrm{Y}$ \\
\hline Establishment specific controls & $\mathrm{N}$ & $\mathrm{N}$ & Y & $\mathrm{Y}$ \\
\hline
\end{tabular}

Notes: Columns 1-3 report estimates of crime expectation on establishment sales, labor, capital and protection (in logs). Each cell reports point estimates from a separate regression. Crime expectation is an indicator for whether an establishment reports crime is a major or severe obstacle to business operation. Column 4 reports estimates when crime expectation is a continuous measure (five values). Establishment-specific controls are related manager experience, number employees at inception, if formally registered at inception and if the establishment is part of a larger establishment. ${ }^{* * *},{ }^{* *},{ }^{*}$ denote significance at the 1,5 and 10 percent level. The $R^{2}$ for specification (3) is approximately 0.35 for sales and capital, and 0.24 for labor and protection.

who report high crime expectation have lower sales, hire fewer workers and spend less on capital than establishments who report low crime expectation. Crime expectation has a smaller magnitude for labor because it is measured in employees while sales and capital are measured in dollar values. When we use log annual cost of labor as the dependant variable, crime expectation lowers establishment spending on labor in the range of 28 - 33 percent, similar to estimates for sales. Column 4 reports crime expectation as a continuous measure $\left(\exp \left(\beta_{i}\right)-1\right) \times 100$, where $\beta_{i}$ is the coefficient of interest. 
and generates results qualitatively similar to those reported in columns $1-3$. As the severity of crime rises (as measured by five indicators) sales and labor falls by 5 and 2 percent. The coefficient for protection expenditure is generally positive but significant only in column 4 establishments spend about 6 percent more on protection as the severity of crime rises.

According to the specification in column 3, which includes all controls, crime expectation has large negative effects on measures related to establishment size in South America, lowering sales and number of employees by 25 and 13 percent. Given that close to one-third of establishments have high crime expectation in the sample, it implies aggregate output losses of about 8 percent percent relative to a crime-free economy, which is larger than the magnitudes founds in general equilibrium macro models of crime/extortion (Ranasinghe 2014; Ranasinghe and Restuccia, 2015). ${ }^{17}$ The effects on capital are negative but not significant.

We also re-run the above specification excluding observations in Brazil. We do this because Brazil accounts for about 25 percent of our sample and close to 70 percent of establishments in Brazil report high crime expectation. Hence, statistical significance of crime expectation maybe driven by and highly sensitive to the inclusion of Brazil. In the Appendix we report these results (Table 9) which confirm that our results are not driven by Brazil. In fact, the coefficient for crime expectation is larger and statistically significant for all dependant variables, including capital investment which falls in the range of $14-20$ percent.

\subsection{Crime expectation across establishment size}

A central prediction of the model in Section 3 is the severity of crime is heterogeneous across size and most prominent among mid-size establishments. For instance, the fraction of capital lost due to crime is initially rising in capital and falls after passing a critical threshold. We now test the validity of this prediction. We re-estimate the effects of crime expectation controlling for country, industry, city and establishment specific effects - separately for small,

\footnotetext{
${ }^{17}$ Treating sales as output, crime lowers output on average by 25 percent for one-third of establishments. Relative to an undistorted economy and absent effects along the extensive margin, this implies output losses of about eight percent $\left(1-\frac{1}{3} \times 0.25\right)$. The quantitative macro models cited above have lower magnitudes due to equilibrium adjustments.
} 
medium and large establishments. The definition for size is from the Enterprise Surveys which classifies an establishment as small, medium or large if the number of full-time employees is between $5-19,20-99$ and greater than $99 .{ }^{18}$ Based on our theory the coefficient on crime expectation $\beta_{2}$, should be larger (more negative) among mid-size establishments than small and large establishments when sales, labor and capital are dependant variables. For protection expenditure we expect that $\beta_{2}$ is positive and increasing in size. Specifically, crime expectation should be associated with a larger response in protection expenditure among large establishments since they have more to lose from crime.

Table 4 reports estimates across establishment size. For sales and labor the coefficient on crime expectation is negative and significant for mid-size establishments, and non-significant for small and large establishments, broadly in-line with the predictions from our theory. For instance, among mid-size establishments, crime expectation lowers sales and number of employees by 30 and 7 percent. The coefficient for capital is negative but not significant among mid-size establishments. For protection, the coefficient for crime expectation is positive and significant across small and large establishments, and not significant across mid-size establishments. We also consider a specification that interacts establishment size categories (small, medium or large) with crime expectation to determine if there are differential effects across size (see Table 11 in Appendix). Consistent with the results reported in Table 4, the coefficient for crime expectation interacted with medium size establishments is negative and statistically significant for sales and labor.

Taken together, crime expectation increases protection spending but has no effect on sales and labor among small and large establishments; in contrast, among mid-size establishments crime expectation is associated with lower sales and labor but has no effect on protection spending. Our theory offers a unified interpretation of these results. Large establishments that have high crime expectation have the most to lose from crime. They respond by raising protection expenditure substantially which reduces the likelihood of crime, and operate close

\footnotetext{
${ }^{18}$ We also considered different definitions for size. The results in Table 4 are generally robust to defining a mid-size establishment as having more than 15 employees.
} 
Table 4: Effect of crime expectation on establishment outcomes, by size

\begin{tabular}{lcccc}
\hline & \multicolumn{4}{c}{ Dependant variable (in logs) } \\
& Sales & Labor & Capital & Protection \\
\hline Sample: small establishments & & & & \\
Crime expectation & 0.000 & 0.023 & 0.014 & $0.290^{* *}$ \\
& $(0.0801)$ & $(0.0250)$ & $(0.1180)$ & $(0.1210)$ \\
Observations & 2204 & 2204 & 1061 & 1061 \\
Sample: mid-size establishments & & & & \\
Crime expectation & $-0.312^{* * *}$ & $-0.073^{* * *}$ & -0.015 & 0.158 \\
& $(0.0754)$ & $(0.0245)$ & $(0.1040)$ & $(0.1250)$ \\
Observations & 2336 & 2336 & 1579 & 1579 \\
Sample: large establishments & & & & \\
Crime expectation & -0.027 & -0.004 & 0.235 & $0.364^{* *}$ \\
& $(0.1040)$ & $(0.0500)$ & $(0.1450)$ & $(0.1560)$ \\
Observations & 1494 & 1494 & 1187 & 1187 \\
& & & & \\
& & & & \\
Country-level controls & $\mathrm{Y}$ & $\mathrm{Y}$ & $\mathrm{Y}$ & $\mathrm{Y}$ \\
$\begin{array}{l}\text { Industry \& city level controls } \\
\text { Establishment specific controls }\end{array}$ & $\mathrm{Y}$ & $\mathrm{Y}$ & $\mathrm{Y}$ & $\mathrm{Y}$ \\
& & $\mathrm{Y}$ & $\mathrm{Y}$ & $\mathrm{Y}$ \\
\hline \hline
\end{tabular}

Notes: This table reports estimates of crime expectation on establishment sales, labor, capital and protection (in logs) across small, medium and large establishments. Each cell reports point estimates from a separate regression. An establishment is small, medium or large if the number of employees is between 5 to 19, 20 to 99 or greater than 99, respectively. Crime expectation is an indicator for whether an establishment reports crime is a major or severe obstacle to business operation. ${ }^{* * *},{ }^{* *}$, * denote significance at the 1,5 and 10 percent level. $R^{2}$ for the regressions related to sales and capital are above 0.35 , and for protection is above 0.2 . $R^{2}$ for labor ranges from $0.08-0.15$. Results for crime expectation interacted with size tell a similar story (see Appendix).

to optimal capacity (relative to large establishments with low crime expectation). Small establishments are not a lucrative target for crime - they have fewer items of value - and those that have high crime expectation need to spend only little on protection to limit the likelihood of crime, and operate close to optimal capacity (relative to small establishments with low crime expectation). For mid-size establishments the margin for adjustment is through production. They are a lucrative target for crime and need to spend a substantial fraction of profit on protection to limit the likelihood of crime. The optimal response for establishments that have high crime expectation is to lower sales and labor because they are not sufficiently profitable to buy adequate protection. These results provide an explanation for the results in 
Hsieh and Klenow (2014) who find that establishments in Mexico and India grow at a slower rate over the life-cycle than establishments in the US. Our results suggest that crime is a contributing factor, especially if small establishments anticipate that future growth comes with the burden of additional crime.

\subsection{Crime and other establishment-level distortions}

As the preceding sections shows, crime expectation is associated with substantial negative effects on establishment outcomes, lowering sales, for example, in the range of $25-30$ percent. While crime is a severe problem in South America, it is merely one among myriad distortions establishments face in day-to-day operations. For instance, access to finance is identified as a major impediment to business expansion and operation (Banerjee and Duflo, 2012; Buera et al. 2011). Likewise, the informal sector can be a drag on formal establishments (D'Erasmo and Moscoso Boedo, 2012; La Porta and Shleifer, 2014), corruption in the form of payingoff bureaucrats to obtain permits can limit growth potential (Dusha, forthcoming), high barriers to entry including transportation development can distort selection (Adamopoulos, 2011; Gollin and Rogerson, 2014; Moscoso Boedo and Mukoyama, 2012) and high tax rates can impede growth (Gollin, 2006). While crime is a severe distortion, how important is crime relative to these other distortions emphasised in the literature?

Ideal for our analysis is the Enterprise Surveys provide comparable 'expectation' data on these distortions which allow us to examine this question. In particular, establishments are asked, across a wide-range of specific distortions, to report whether a given distortion is a severe, major, moderate, minor or non-obstacle to business operation. We focus on functioning of the courts system, access to finance, practices of the informal sector, tax rates, transportation and corruption, and examine their effects on measures related to establishment size in comparison to those for crime. We define 'expectation' variables for these distortions similar to crime expectation - for example, we set 'corruption expectation' equal to one if an establishment reports corruption is a major/severe obstacle to business operation, and zero 
Table 5: Effects of crime relative to other distortions

\begin{tabular}{|c|c|c|c|c|c|}
\hline & \multicolumn{5}{|c|}{ Dependant variable (in logs) } \\
\hline & Sales & Labor & Capital & Protection & Sales (mid-size) \\
\hline Crime expectation & $\begin{array}{c}-0.229^{* * *} \\
(0.0638)\end{array}$ & $\begin{array}{c}-0.106^{* * *} \\
(0.0339)\end{array}$ & $\begin{array}{c}-0.134 \\
(0.0817)\end{array}$ & $\begin{array}{c}0.0384 \\
(0.0929)\end{array}$ & $\begin{array}{c}-0.315^{* * *} \\
(0.0808)\end{array}$ \\
\hline Corruption expectation & $\begin{array}{c}-0.212^{* * *} \\
(0.0649)\end{array}$ & $\begin{array}{c}-0.119^{* * *} \\
(0.0360)\end{array}$ & $\begin{array}{c}-0.072 \\
(0.0835)\end{array}$ & $\begin{array}{c}-0.096 \\
(0.0932)\end{array}$ & $\begin{array}{c}-0.054 \\
(0.0799)\end{array}$ \\
\hline Courts expectation & $\begin{array}{l}0.288^{* * *} \\
(0.0675)\end{array}$ & $\begin{array}{l}0.090^{* *} \\
(0.0365)\end{array}$ & $\begin{array}{l}0.349^{* * *} \\
(0.0844)\end{array}$ & $\begin{array}{l}0.321^{* * *} \\
(0.0975)\end{array}$ & $\begin{array}{c}0.180^{*} \\
(0.0837)\end{array}$ \\
\hline Finance expectation & $\begin{array}{c}-0.363^{* * *} \\
(0.0644)\end{array}$ & $\begin{array}{c}-0.182^{* * *} \\
(0.0333)\end{array}$ & $\begin{array}{c}-0.159^{*} \\
(0.0855)\end{array}$ & $\begin{array}{c}-0.287^{* * *} \\
(0.0963)\end{array}$ & $\begin{array}{c}-0.203^{* *} \\
(0.0833)\end{array}$ \\
\hline Informal sector expectation & $\begin{array}{c}-0.329^{* * *} \\
(0.0564)\end{array}$ & $\begin{array}{c}-0.189^{* * *} \\
(0.0307)\end{array}$ & $\begin{array}{c}-0.146^{*} \\
(0.0733)\end{array}$ & $\begin{array}{c}-0.104 \\
(0.0825)\end{array}$ & $\begin{array}{c}-0.149^{* *} \\
(0.0708)\end{array}$ \\
\hline Tax-rate expectation & $\begin{array}{c}0.055 \\
(0.0622)\end{array}$ & $\begin{array}{c}0.024 \\
(0.0361)\end{array}$ & $\begin{array}{c}-0.025 \\
(0.0801)\end{array}$ & $\begin{array}{c}-0.006 \\
(0.0898)\end{array}$ & $\begin{array}{c}0.100 \\
(0.0772)\end{array}$ \\
\hline Transportation expectation & $\begin{array}{l}0.264^{* * *} \\
(0.0648)\end{array}$ & $\begin{array}{l}0.193^{* * *} \\
(0.0351)\end{array}$ & $\begin{array}{c}0.076 \\
(0.0824)\end{array}$ & $\begin{array}{c}0.238^{* *} \\
(0.0937)\end{array}$ & $\begin{array}{c}0.113 \\
(0.0811)\end{array}$ \\
\hline Country-level controls & $\mathrm{Y}$ & $\mathrm{Y}$ & $\mathrm{Y}$ & $\mathrm{Y}$ & $\mathrm{Y}$ \\
\hline Industry \& country level controls & $\mathrm{Y}$ & $\mathrm{Y}$ & $\mathrm{Y}$ & $\mathrm{Y}$ & $\mathrm{Y}$ \\
\hline Establishment specific controls & $\mathrm{Y}$ & $\mathrm{Y}$ & $\mathrm{Y}$ & $\mathrm{Y}$ & $\mathrm{Y}$ \\
\hline Observations & 6076 & 6075 & 3841 & 3841 & 2236 \\
\hline$R^{2}$ & 0.39 & 0.25 & 0.35 & 0.24 & 0.46 \\
\hline
\end{tabular}

Notes: This table reports estimates of various distortions on establishment sales, labor, capital expenditure and protection expenditure. Each expectation variable is an indicator for whether an establishment reports the given expectation is a major or severe obstacle to business operation. The last column reports the effects of expectation variables on sales among mid-size establishments. Results for labor among mid-size establishments are similar to those reported in the preceding column. ${ }^{* * *},{ }^{* *},{ }^{*}$ denote significance at the 1,5 and 10 percent level.

otherwise. We then re-estimate equation 7 by including these additional distortions together with crime.

Table 5 reports the effects of these distortions on sales, labor, capital and protection, after controlling for country, industry, city and establishment productivity controls as before. There are several key results that stand-out. Crime, access to finance, corruption and informal sector expectation have negative and significant effects on sales, labor and capital, while functioning of courts and transportation have positive and significant effects on the four dependant variables. We discuss the implications of these in turn. 
Crime expectation is associated with a 20, 10 and 13 percent reduction in sales, labor and capital, essentially the same values found in Table 3 (capital is marginally non-significant at the 10 percent level). Finance expectation, net of other distortions, has the largest coefficient and is associated with a 30, 16 and 15 percent reduction in sales, capital and labor. The coefficient for informal sector (corruption) expectation are generally higher (lower) in magnitude than those for crime expectation. The point here is not necessarily the size of these coefficients - in fact, we cannot reject that the effects of crime expectation on sales, capital and labor are statistically different from those related access to finance, informal sector or corruption - but rather to highlight that crime remains an important determinant of establishment size after controlling for these additional distortions. From a policy perspective crime may be an equally important obstacle to business operation as these other distortions examined in the literature, at least in South America. Moreover, given that improving access to finance is a policy tool for development often emphasized, our results suggest that policies that strive to lower crime can also have an important role for spurring enterprise (Johnson et al., 2012).

We also re-estimate the effects of these 'expectations' separately for small, medium and large establishments. Consistent with the results from Table 4, crime is most problematic among mid-size establishments. This can be seen in the last column of Table 5 which reports the effects of these distortions on sales among mid-size establishments. The coefficient for crime expectation is larger than the coefficients for access to finance, informal sector and corruption, though not statistically different. The results are similar across capital and labor for mid-size establishments as well.

Also of interest, the coefficients for courts and transportation expectation are uniformly positive (and significant in all but one instance) across the four dependant variables. That is to say, establishments that view functioning of courts or transportation as a major or severe obstacle to business operation on average have higher sales, labor, capital and protection. This maybe due to courts and transportation picking-up establishments that patent, innovate 
and/or export; essentially high growth establishments. However, since we control across 20 industries it is not clear which effects are being isolated. We also control for export status and R\&D spending across small, medium and large establishments, however, do not find systematic patterns in favor of a particular view.

\subsection{Robustness}

Inputs in production and losses due to crime at the establishment-level are endogenous outcomes. The rationale in using crime expectation is that it captures an establishment's belief or perception of the severity of crime, and is therefore informative of how crime affects establishment decisions related to size. However, what we have is crime expectation at the end, not at the start of the period. If crime expectation is influenced by current period losses from crime, then crime expectation itself may be an endogenous outcome and thereby bias our results. We now aim to address this concern.

About one-third of establishments in our sample report facing crime. Not surprisingly, the percentage who report high crime expectation is higher among establishments that faced crime than among those who did not face crime (45 vs. 28 percent). Even though the correlation between facing crime and high crime expectation is low (16 percent), the preceding numbers imply that facing crime may influence expectation of crime. To account for this, we re-estimate equation 7 for firms that face crime and those that did not separately. These regressions provide evidence whether the effects of crime expectation on establishment outcomes systematically differ across the sub-groups.

Table 6 reports estimates for crime expectation on outcome variables among these subgroups (columns $1-2$ ) and among mid-size establishments that did and did not face crime (columns $3-4$ ). The results tell a similar story to those already reported. The coefficient for crime expectation is negative for sales, labor and capital; they are also larger among establishments that faced crime than those who did not. We assume if an establishment does not face crime, crime expectation between the start and end of period should fall or remain 
Table 6: Effects of Crime expectation across sub-samples

\begin{tabular}{|c|c|c|c|c|}
\hline & $\begin{array}{c}(1) \\
\text { Faced Crime }\end{array}$ & $\begin{array}{c}(2) \\
\text { Did not Face Crime }\end{array}$ & $\begin{array}{l}\text { Faced Crime } \\
\text { (mid-size) }\end{array}$ & $\begin{array}{l}\text { (4) } \\
\text { Did not Face Crime } \\
\text { (mid-size) }\end{array}$ \\
\hline Sales $(\log s)$ & $\begin{array}{c}-0.424^{* * *} \\
(0.0962)\end{array}$ & $\begin{array}{c}-0.323^{* * *} \\
(0.0769)\end{array}$ & $\begin{array}{c}-0.410^{* * *} \\
(0.116)\end{array}$ & $\begin{array}{c}-0.269^{* * *} \\
(0.1020)\end{array}$ \\
\hline Observations & 1914 & 4162 & 765 & 1571 \\
\hline Labor (logs) & $\begin{array}{c}-0.230^{* * *} \\
(0.0568)\end{array}$ & $\begin{array}{c}-0.185^{* * *} \\
(0.0383)\end{array}$ & $\begin{array}{l}-0.094^{* *} \\
(0.0400)\end{array}$ & $\begin{array}{c}-0.079^{* *} \\
(0.0319)\end{array}$ \\
\hline Observations & 1914 & 4161 & 765 & 1571 \\
\hline Capital (logs) & $\begin{array}{l}-0.120 \\
(0.123)\end{array}$ & $\begin{array}{l}-0.162 \\
(0.1000)\end{array}$ & $\begin{array}{l}-0.059 \\
(0.1710)\end{array}$ & $\begin{array}{l}-0.013 \\
(0.1380)\end{array}$ \\
\hline Observations & 1339 & 2502 & 554 & 1025 \\
\hline Protection (logs) & $\begin{array}{c}0.028 \\
(0.133)\end{array}$ & $\begin{array}{l}-0.029 \\
(0.1130)\end{array}$ & $\begin{array}{c}0.112 \\
(0.193)\end{array}$ & $\begin{array}{c}0.133 \\
(0.1720)\end{array}$ \\
\hline Observations & 1339 & 2502 & 554 & 1025 \\
\hline $\begin{array}{l}\text { Country-level controls } \\
\text { Industry \& city level controls } \\
\text { Establishment specific controls }\end{array}$ & $\begin{array}{l}\mathrm{Y} \\
\mathrm{Y} \\
\mathrm{Y}\end{array}$ & $\begin{array}{l}\mathrm{Y} \\
\mathrm{Y} \\
\mathrm{Y}\end{array}$ & $\begin{array}{l}\text { Y } \\
\text { Y } \\
\text { Y }\end{array}$ & $\begin{array}{l}\text { Y } \\
\text { Y } \\
\text { Y }\end{array}$ \\
\hline
\end{tabular}

Notes: Columns 1-2 report estimates of crime expectation on establishment sales, labor, capital and protection (in logs) among establishments that did and did not face crime. Columns 3-4 report the same estimates among mid-size establishments. Estimates for small and large establishments among those who did and did not face crime are not significant. Each cell reports point estimates from a separate regression. Crime expectation is an indicator for whether an establishment reports crime is a major or severe obstacle to business operation. Establishment-specific controls are related manager experience, number employees at inception, if formally registered at inception and if the establishment is part of a larger establishment. ${ }^{* * *},{ }^{* *},{ }^{*}$ denote significance at the 1,5 and 10 percent level.

unchanged. Under this premise, establishments that did not face crime and report high crime expectation should have high crime expectation at the start of the period as well. That crime expectation is statistically significant for sales and labor - and marginally non-significant at the 10 percent level for capital - among establishments that did not face crime is supportive that our results are not driven by current period losses from crime. We also find that crime is most problematic among mid-size establishments and is robust to whether an establishment 
has or has not faced crime in the current period. ${ }^{19}$

Lagged crime expectation: While the preceding table shows that our results are not driven by establishments that faced crime, it nonetheless does not fully resolve issues related to endogeneity, arising in part due to reverse causality. For instance, it may be that establishment size is driving crime expectation, instead of the other way around. To address this we replace current crime expectation with lagged crime expectation. In particular, we evaluate the effects of crime expectation in 2006 on establishment decisions in 2010 (OLS regressions). The underlying premise is that lagged crime expectation has a one-directional and plausibly causal interpretation: crime expectation in 2006 can influence future establishment decisions (in 2010), but not the other way around.

There are two main limitations to this approach. First, the Enterprise Surveys are conducted over a four-year span, which implies a four-year gap between lagged crime expectation and establishment decisions. In particular, establishments may update their expectation based on more recent episodes of crime. However, this is what our first robustness check is intended to account for: by restricting the sample to establishments who did not face crime in the current period, we are capturing the effects of previous incidents of crime (and thus current expectation of crime) on establishment outcomes. A second limitation is the sample size is considerably smaller for the panels. We also exclude Brazil because its panel is for 2003 and 2009. To maintain as much of the panel as possible we restrict industry controls to two aggregated ones - manufacturing and non-manufacturing - instead of 30 separate industries. We are left with a quarter of the original sample used in our previous results (from about 6000 observations to 1500 for sales and labor, and from over 3500 observations to about 900 for capital and protection).

With these limitations in mind, Table 7 reports the results for lagged crime expectation on establishment outcomes. Columns $1-3$ report results when country, aggregated industry

\footnotetext{
${ }^{19}$ The effects of crime expectation on sales, labor, capital and protection are not significant for small and large establishments, across the two sub-groups, similar to earlier results.
} 
Table 7: Effect of lagged crime expectation on establishment outcomes

\begin{tabular}{|c|c|c|c|c|}
\hline & (1) & $(2)$ & (3) & (4) \\
\hline \multicolumn{5}{|l|}{ Dependant: sales (logs) } \\
\hline Lagged crime expectation & $\begin{array}{c}-0.236^{* *} \\
(0.1030)\end{array}$ & $\begin{array}{c}-0.224^{* *} \\
(0.1030)\end{array}$ & $\begin{array}{c}-0.134 \\
(0.0953)\end{array}$ & $\begin{array}{c}-0.271^{* * *} \\
(0.0965)\end{array}$ \\
\hline Observations & 1482 & 1482 & 1482 & 1482 \\
\hline \multicolumn{5}{|l|}{ Dependant: labor (logs) } \\
\hline Lagged crime expectation & $\begin{array}{c}-0.158^{* *} \\
(0.0718)\end{array}$ & $\begin{array}{l}-0.135^{*} \\
(0.0715)\end{array}$ & $\begin{array}{c}-0.062 \\
(0.0655)\end{array}$ & $\begin{array}{l}-0.122^{*} \\
(0.0654)\end{array}$ \\
\hline Observations & 1481 & 1481 & 1481 & 1481 \\
\hline \multicolumn{5}{|l|}{ Dependant: capital $(\operatorname{logs})$} \\
\hline Lagged crime expectation & $\begin{array}{c}-0.401^{* * *} \\
(0.1330)\end{array}$ & $\begin{array}{c}-0.380^{* * *} \\
(0.1440)\end{array}$ & $\begin{array}{c}-0.297^{* *} \\
(0.1310)\end{array}$ & $\begin{array}{l}-0.226^{*} \\
(0.1270)\end{array}$ \\
\hline Observations & 900 & 900 & 900 & 900 \\
\hline \multicolumn{5}{|l|}{ Dependant: protection $(\operatorname{logs})$} \\
\hline Lagged crime expectation & $\begin{array}{c}-0.191 \\
(0.1400)\end{array}$ & $\begin{array}{c}-0.157 \\
(0.1390)\end{array}$ & $\begin{array}{c}-0.066 \\
(0.1340)\end{array}$ & $\begin{array}{c}-0.036 \\
(0.1390)\end{array}$ \\
\hline Observations & 900 & 900 & 900 & 900 \\
\hline Country-level controls & $\mathrm{Y}$ & $\mathrm{Y}$ & $\mathrm{Y}$ & $\mathrm{Y}$ \\
\hline Aggregated industry \& city level controls & $\mathrm{N}$ & Y & $\mathrm{Y}$ & $\mathrm{Y}$ \\
\hline Establishment specific controls & $\mathrm{N}$ & $\mathrm{N}$ & Y & Y \\
\hline
\end{tabular}

Notes: This table reports OLS estimates of lagged crime expectation on establishment current sales, labor, capital expenditure and protection expenditure, in logs. Each cell reports point estimates from a separate regression. Column 4 reports the effects of crime expectation (non-lagged) using approximately equivalent sample as those reported in Columns 1-3. Crime expectation is an indicator for whether an establishment reports crime is a major or severe obstacle to business operation. Establishment-specific controls are related manager experience, number employees at inception, if formally registered at inception and if the establishment is part of a larger establishment. ${ }^{* *},{ }^{* *},{ }^{*}$ denote significance at the 1,5 and 10 percent level.

and city, and productivity fixed effects are sequentially included. We also report effects of crime expectation (non-lagged) on outcome variables using the same aggregated industry controls in column 4, so the magnitudes can be easily compared with those in column 3. Lagged crime expectation is associated with approximately a 20 and 13 percent reduction in sales and labor (columns $1-2$ ). When establishment productivity controls are included estimates for sales and labor are negative but not significant, and are considerably smaller than those reported in column 4 (when non-lagged crime expectation is the regressor). How- 
ever, the coefficient for lagged crime expectation on capital is negative and significant under all specifications: establishments that report high lagged crime expectation spend about 26 percent less on capital investment (column 3). While this is in part due to a coarser definition of industry, it is nonetheless larger than the coefficient for capital reported in column 4 . The effects of lagged crime expectation on protection are negative and not significant under all specifications.

Instrumental Variable Approach: As a final approach to support a causal interpretation of our results we adopt an instrumental variable strategy using crime expectation averages. Specifically, in the first-stage we regress average crime expectation within country, industry and city, together with dummy variables for establishment size (small, medium or large) and previous controls on establishment-level crime expectation. ${ }^{20}$ In the second stage we regress predicted crime expectation and previous control variables on measures related to establishment size (sales, labor, capital and protection). To have a causal interpretation we need to assume that average crime expectation (within country, industry and city) affects measures related to size only through its effect on establishment-level crime expectation. While this may be a strong identification assumption it serves as an additional test, together with our previous tests, for evaluating the effects of crime on establishment outcomes.

Columns $1-2$ in Table 8 presents estimates when crime expectation is an indicator variable and columns $3-4$ when crime expectation is a continuous variable taking five possible values. Notable is the coefficients for crime expectation on sales and capital are negative and significant; labor and protection are not significant. The estimates imply that crime expectation (discrete variable) reduces sales and capital by 43 and 53 percent, which are considerably larger than the OLS estimates reported in Table 3 and lagged crime expectation estimates reported in Table 7. The estimates for crime expectation as a continuous variable imply that an increase in the severity of crime reduces sales and capital by 20 and 30 percent.

\footnotetext{
${ }^{20}$ In using the average crime expectation instrument, we only consider those that have 10 or more observations in each grouping.
} 
Table 8: IV results - average crime expectation within country, industry and city

\begin{tabular}{|c|c|c|c|c|}
\hline & $(1)$ & $(2)$ & $(3)$ & $(4)$ \\
\hline \multicolumn{5}{|l|}{ Dependant: sales (logs) } \\
\hline Crime expectation & $\begin{array}{c}-0.561^{* *} \\
(0.252)\end{array}$ & $\begin{array}{c}-0.559^{* *} \\
(0.250)\end{array}$ & $\begin{array}{c}-0.235^{* * *} \\
(0.091)\end{array}$ & $\begin{array}{c}-0.226^{* *} \\
(0.090)\end{array}$ \\
\hline Observations & 2182 & 2182 & 2182 & 2182 \\
\hline \multicolumn{5}{|l|}{ Dependant: labor (logs) } \\
\hline Crime expectation & $\begin{array}{c}0.013 \\
(0.124)\end{array}$ & $\begin{array}{c}0.014 \\
(0.121)\end{array}$ & $\begin{array}{l}-0.016 \\
(0.046)\end{array}$ & $\begin{array}{l}-0.013 \\
(0.045)\end{array}$ \\
\hline Observations & 2182 & 2182 & 2182 & 2182 \\
\hline \multicolumn{5}{|l|}{ Dependant: capital (logs) } \\
\hline Crime expectation & $\begin{array}{c}-0.734^{*} \\
(0.379)\end{array}$ & $\begin{array}{c}-0.772^{* *} \\
(0.376)\end{array}$ & $\begin{array}{c}-0.355^{* *} \\
(0.144)\end{array}$ & $\begin{array}{c}-0.364^{* *} \\
(0.144)\end{array}$ \\
\hline Observations & 1327 & 1327 & 1327 & 1327 \\
\hline \multicolumn{5}{|l|}{ Dependant: protection $(\operatorname{logs})$} \\
\hline Crime expectation & $\begin{array}{l}-0.497 \\
(0.425)\end{array}$ & $\begin{array}{l}-0.470 \\
(0.421)\end{array}$ & $\begin{array}{l}-0.263 \\
(0.162)\end{array}$ & $\begin{array}{l}-0.254 \\
(0.162)\end{array}$ \\
\hline Observations & 1327 & 1327 & 1327 & 1327 \\
\hline Country, industry \& level controls & $\mathrm{Y}$ & $\mathrm{Y}$ & $\mathrm{Y}$ & Y \\
\hline Size controls & Y & $\mathrm{Y}$ & Y & Y \\
\hline Establishment specific controls & $\mathrm{N}$ & $\mathrm{Y}$ & $\mathrm{N}$ & $\mathrm{Y}$ \\
\hline
\end{tabular}

Notes: This table reports estimates when average crime expectation within a city, industry and country is used as an instrument for crime expectation. Columns $1-2(3-4)$ are when establishmentlevel crime expectation is an indicator variable (continuous variable - a severe, major, moderate, minor or non-obstacle to doing business). Size controls are dummy variables for small, medium and large establishments, where a medium size establishment is one that has between $20-99$ employees. Each cell reports the point estimates from a separate IV regression. ${ }^{* *},{ }^{* *},{ }^{*}$ denote significance at the 1,5 and 10 percent level.

These estimates are also considerably larger than the OLS estimates reported in Table 3. The estimates for labor and protection are not significant.

Notable is that under the lagged crime and IV approaches, we find that high crime expectation has a substantial effect in lowering establishment capital investment. This result is consistent with Johnson et al. (2002) who find that among transition, post-Communist European countries where property rights are weak, firms re-invest considerably less in their business due to expropriation. Our results show this effect is clearly evident and acute in South 
America, and is an important factor for understanding establishment under-performance in this region.

\section{Conclusion}

In this paper we document that crime is a frequent occurrence and one of the biggest obstacles to doing business in South America. To account for its effects we present a simple theory to highlight that establishments strategically under-produce in order to mitigate losses from crime. Our theory implies that losses from crime and establishment size are co-dependant variables, and generate testable predictions that we validate against the data. We use crime expectation, which captures an establishment's belief regarding the severity of crime for business operation, to evaluate its effects on measures related to establishment size. We find that establishments who report high crime expectation are strongly associated with lower sales, labor and capital. Consistent with the predictions of our theory, crime is most problematic among mid-size establishments lowering sales in the range of 30 percent. We also evaluate the importance of crime relative to other distortions emphasized in the literature, notably access to finance, the informal sector and corruption. Our results confirm that crime is one of the biggest obstacles to business performance even after we control for these factors.

We also consider several specifications that are tenable to a causal interpretation of crime on measures related to size: across sub-samples for establishments that did and did not face crime, using lagged crime expectation and an IV approach that uses average crime expectation by country, industry and city. Across these specifications we find overwhelming and consistent evidence that high crime expectation lowers sales, labor and capital investment. Taken together, our results imply that lowering crime maybe one of the more relevant policy reforms for spurring development. 


\section{References}

Adamopoulos, T. (2011). Transportation Costs, Agricultural Productivity, and Cross-Country Income Differences. International Economic Review, 52(2), 489-521.

Banerjee, A. and E. Duflo. 2014. Do Firms Want to Borrow More? Testing Credit Constraints Using a Directed Lending Program. Review of Economic Studies, 81 (2), 572-607.

Bartelsman, E., Haltiwanger, J., Scarpetta, S., 2013. Cross Country Differences in Productivity: The Role of Allocation and Selection. The American Economic Review, 103 (1), 305-334.

Bento, P., and D. Restuccia. 2015. Misallocation, Establishment Size and Productivity. mimeo.

Bloom, N., and J. Van Reenen. 2007. Measuring and Explaining Management Practices Across Firms and Countries. Quarterly Journal of Economics, 122 (4), 1351-1408.

Bloom, N., B. Eifert, A. Mahajan, D. McKenzie and J. Roberts. 2013. Does Management Matter? Evidence From India. Quarterly Journal of Economics, 128 (1), 1-51.

Buera, F., J. Kaboski and Y. Shin. 2011. Finance and Development: A Tale of Two Sectors. American Economic Review, 101(5), 1964-2002.

Brunetti, A., G. Kisunko., and B. Weder. 1997. Institutional obstacles to doing business: region-by-region results from a worldwide survey of the private sector. Vol. 1759. World Bank Publications, 1997.

D'Erasmo, P. and H. Moscoso Boedo. 2012. Financial Structure, Informality and Development. Journal of Monetary Economics, 59(3), 286-302.

Dell, M. 2015. Trafficking Networks and the Mexican Drug War. American Economic Review, 105(6), 1738-1779. 
Di Tella, R, and E. Schargrodsky. 2004. Do Police Reduce Crime? Estimates Using the Allocation of Police Forces After a Terrorist Attack. American Economic Review, 94(1), $115-133$.

Dusha, E. (forthcoming). Intermediated Corruption. International Economic Review.

Fajnzylber, P., D. Lederman, and N. Loayza. 1998. Determinants of Crime Rates in Latin America and the World: An Empirical Assessment. World Bank Latin American and Caribbean Studies, World Bank Publications 18544.

Glaeser, E., B. Sacerdote., and J. Scheinkman. 1996. Crime and Social Interactions. Quarterly Journal of Economics, 111, 507-548.

Gollin, D. 2006. Do Taxes on Large Firms Impede Growth? Evidence from Ghana. mimeo.

Gollin, D, and R. Rogerson. 2014. Productivity, Transportations Costs and Subsistence Agriculture. Journal of Development Economics, 107, 38-48.

Guner, N., Ventura, G., Xu, D., 2008. Macroeconomic implications of size dependent policies. Review of Economic Dynamics 11(4), 721-744.

Hsieh, C, and P. Klenow. 2009. Misallocation and Manufacturing TFP in China and India. Quarterly Journal of Economics, 124(4), 1403-1448.

Hsieh, C, and P. Klenow. The life cycle of plants in India and Mexico. Quarterly Journal of Economics, 129(2), 1035-1084.

Johnson, S., J. McMillan. and C. Woodruff. 2002. Property Rights and Finance. American Economic Review, 92(5), 1335-1356.

Kalemli-Ozcan, S., and B. Sorensen. 2012. Misallocation, Property Rights, and Access to Finance: Evidence from Within and Across Africa. NBER Working Paper Series, 18030. 
La Porta, R. and A. Shleifer. 2014. Informality and Development. Journal of Economic Perspectives, 28(3), 109-126.

Midrigan, V. and D. Xu. 2014. Finance and Misallocation: Evidence from Plant-Level Data. American Economic Review, 104(2), 422-458.

Miron, J. 2001. Violence, Guns and Drugs: A Cross-Country Analysis. Journal of Law and Economics, 2(2), 615-634.

Moscoso Boedo, H. and T. Mukoyama. 2012. Evaluating the Effects of Entry Regulations and Firing Costs on International Income Differences. Journal of Economic Growth, 17(2), $143-170$.

Munyo, I. 2015. The juvenile crime dilemma. Review of Economic Dynamics, 18(2), 201-211.

Ranasinghe, A. 2014. Property Rights, Extortion and the Misallocation of Talent. mimeo.

Ranasinghe, A and D. Restuccia. 2014. Financial frictions and the rule of law. mimeo.

Restuccia, D and R. Rogerson. 2008. Policy Distortions and aggregate productivity with heterogeneous establishments. Review of Economic Dynamics, 11(4), 707-720.

Svensson, Jakob. 1998. Investment, Property Rights and Political Instability: Theory and Evidence. European Economic Review, 42(7), 1317-1341.

Toth, R. 2014. Experience Does Matter: Managerial Capital and the Dynamics of Entrepreneurship. mimeo.

Treisman, D. 2000. The causes of corruption: a cross-national study. Journal of Public Economics, 76, 399-457. 
Table 9: Effect of crime in South America (excluding Brazil)

\begin{tabular}{|c|c|c|c|c|}
\hline & $(1)$ & $(2)$ & $(3)$ & $(4)$ \\
\hline \multicolumn{5}{|l|}{ Dependant: sales $(\operatorname{logs})$} \\
\hline Crime expectation & $\begin{array}{c}-0.370^{* * *} \\
(0.0619)\end{array}$ & $\begin{array}{c}-0.360^{* * *} \\
(0.0602)\end{array}$ & $\begin{array}{c}-0.321^{* * *} \\
(0.0557)\end{array}$ & $\begin{array}{r}-0.064^{* *} \\
(0.0198)\end{array}$ \\
\hline Observations & 4553 & 4553 & 4553 & 4553 \\
\hline \multicolumn{5}{|l|}{ Dependant: labor (logs) } \\
\hline Crime expectation & $\begin{array}{c}-0.212^{* * *} \\
(0.0433)\end{array}$ & $\begin{array}{c}-0.193^{* * *} \\
(0.0425)\end{array}$ & $\begin{array}{c}-0.162^{* * *} \\
(0.0383)\end{array}$ & $\begin{array}{c}-0.016 \\
(0.0136)\end{array}$ \\
\hline Observations & 4552 & 4552 & 4552 & 4552 \\
\hline \multicolumn{5}{|l|}{ Dependant: capital (logs) } \\
\hline Crime expectation & $\begin{array}{c}-0.225^{* * *} \\
(0.0744)\end{array}$ & $\begin{array}{c}-0.196^{* * *} \\
(0.0736)\end{array}$ & $\begin{array}{c}-0.152^{* *} \\
(0.0707)\end{array}$ & $\begin{array}{c}-0.044^{*} \\
(0.0257)\end{array}$ \\
\hline Observations & 2823 & 2823 & 2823 & 2823 \\
\hline \multicolumn{5}{|l|}{ Dependant: protection $(\operatorname{logs})$} \\
\hline Crime expectation & $\begin{array}{c}-0.192^{* *} \\
(0.0824)\end{array}$ & $\begin{array}{c}-0.175^{* *} \\
(0.0815)\end{array}$ & $\begin{array}{c}-0.115 \\
(0.0778)\end{array}$ & $\begin{array}{c}0.023 \\
(0.0281)\end{array}$ \\
\hline Observations & 2823 & 2823 & 2823 & 2823 \\
\hline Country-level controls & $\mathrm{Y}$ & $\mathrm{Y}$ & $\mathrm{Y}$ & $\mathrm{Y}$ \\
\hline Industry \& country level controls & $\mathrm{N}$ & $\mathrm{Y}$ & Y & $\mathrm{Y}$ \\
\hline Establishment specific controls & $\mathrm{N}$ & $\mathrm{N}$ & $\mathrm{Y}$ & $\mathrm{Y}$ \\
\hline
\end{tabular}

Notes: This table is identical to the one in Table 3 but excludes establishment observations in Brazil. Columns 1-3 report the estimates of crime expectation on establishment sales, labor (number of fulltime employees), capital expenditure (in the given year) and protection expenditure, in logs. Each cell reports the point estimates from a separate regression. Crime expectation is an indicator for whether an establishment reports that crime is a major or severe obstacle to business operation. Column 4 reports the estimates when crime expectation is a continuous measure (five values). Establishmentspecific controls are related manager experience, number employees at inception, if formally registered at inception and if the establishment is part of a larger establishment. ${ }^{* * *},{ }^{* *},{ }^{*}$ denote significance at the 1,5 and 10 percent level. 
Table 10: Effect of crime on establishment outcomes, by size (excluding Brazil)

\begin{tabular}{|c|c|c|c|c|}
\hline & \multicolumn{4}{|c|}{ Dependant variable (in logs) } \\
\hline & Sales & Labor & Capital & Protection \\
\hline Sample: small establishments & & & & \\
\hline Crime expectation & $\begin{array}{c}-0.049 \\
(0.0662)\end{array}$ & $\begin{array}{c}0.006 \\
(0.0241)\end{array}$ & $\begin{array}{c}0.175^{*} \\
(0.0977)\end{array}$ & $\begin{array}{c}-0.045 \\
(0.0952)\end{array}$ \\
\hline Observations & 1554 & 1554 & 700 & 700 \\
\hline Sample: mid-size establishments & & & & \\
\hline Crime expectation & $\begin{array}{c}-0.237^{* * *} \\
(0.0590)\end{array}$ & $\begin{array}{l}-0.051^{*} \\
(0.0270)\end{array}$ & $\begin{array}{c}0.124 \\
(0.0883)\end{array}$ & $\begin{array}{c}0.003 \\
(0.105)\end{array}$ \\
\hline Observations & 1743 & 1743 & 1149 & 1149 \\
\hline Sample: large establishments & & & & \\
\hline Crime expectation & $\begin{array}{c}-0.098 \\
(0.0833)\end{array}$ & $\begin{array}{c}0.007 \\
(0.0545)\end{array}$ & $\begin{array}{c}0.079 \\
(0.133)\end{array}$ & $\begin{array}{c}0.288^{*} \\
(0.1450)\end{array}$ \\
\hline Observations & 1224 & 1224 & 960 & 960 \\
\hline Country level controls & Y & $\mathrm{Y}$ & Y & $\mathrm{Y}$ \\
\hline Industry \& city level controls & Y & Y & Y & Y \\
\hline Establishment specific controls & Y & $\mathrm{Y}$ & $\mathrm{Y}$ & Y \\
\hline
\end{tabular}

Notes: This table is identical to the one in Table 4 but excludes establishment observations in Brazil. It reports estimates of crime expectation on establishment sales, labor, capital expenditure and protection expenditure, for small, medium and large establishments. Each cell reports point estimates from a separate regression. An establishment is small, medium or large if the number of employees is between 5 to 19, 20 to 99 or greater than 99, respectively. Crime expectation is an indicator for whether an establishment reports crime is a major or severe obstacle to business operation. ${ }^{* *},{ }^{* *},{ }^{*}$ denote significance at the 1,5 and 10 percent level. 
Table 11: Crime and Size interaction

\begin{tabular}{lcccc}
\hline & \multicolumn{4}{c}{ Dependant variable (in logs) } \\
& Sales & Labor & Capital & Protection \\
\hline \multirow{3}{*}{ Crime expectation $\times$ small } & $-0.009^{* * *}$ & $0.061^{* *}$ & -0.062 & 0.171 \\
& $(0.0789)$ & $(0.0254)$ & $(0.1170)$ & $(0.1240)$ \\
& & & & \\
Crime expectation $\times$ medium & $-0.306^{* * *}$ & $-0.164^{* * *}$ & 0.083 & -0.014 \\
& $(0.1070)$ & $(0.0345)$ & $(0.1530)$ & $(0.1700)$ \\
Crime expectation $\times$ large & -0.032 & $-0.096^{*}$ & 0.288 & $0.352^{*}$ \\
& $(0.1290)$ & $(0.0536)$ & $(0.1810)$ & $(0.1950)$ \\
& & & & \\
Country-level controls & & & & \\
Industry \& city level controls & $\mathrm{Y}$ & $\mathrm{Y}$ & $\mathrm{Y}$ & $\mathrm{Y}$ \\
Establishment specific controls & $\mathrm{Y}$ & $\mathrm{Y}$ & $\mathrm{Y}$ & $\mathrm{Y}$ \\
\hline Observations & 6034 & 6034 & 3827 & 3827 \\
$R^{2}$ & 0.61 & 0.78 & 0.47 & 0.39 \\
\hline \hline
\end{tabular}

Notes: This table reports estimates of crime expectation interacted with establishment size. Crime expectation is an indicator variable for whether an establishment reports crime expectation is a major or severe obstacle to business operation. Dummy variables for small, medium and large establishments are based on number of employees: $5-19,20-99$ and $>99 .{ }^{* * *},{ }^{* *},{ }^{*}$ denote significance at the 1,5 and 10 percent level. The effects of crime expectation interacted with medium size establishments is significant at the 1 percent level for sales and labor, and crime expectation interacted with large establishments is significant at the 1 percent level for protection. 